\title{
Archipelagic Nationalism and Chinese Food Culture in New Order Indonesia: Making Indonesian Food, Erasing Chinese Food
}

\author{
Michael P. Oman-Reagan \\ Department of Anthropology \\ Memorial University of Newfoundland
}

\begin{abstract}
:
This paper examines the history of Indonesian nationalism in terms of relationships with Chinese food culture. The paper explores how colonial inheritances, assimilationist ideology and the emergence of an archipelagic nationalism included and excluded Chinese foodways in New Order era embargoes on and erasures of Chinese cultural expression. By looking at the way food was and was not included in the bans on public performances of Chinese culture, I explore how Chinese-Indonesian culture was constructed, produced, and framed in the New Order era in light of the culture bans. I do this by first looking for the historical roots of New Order nationalism and assimilation and seeking to understand how these relations of power informed what was considered Indonesian and what was considered Chinese. I then look at how the Chinese origin of Indonesian food culture was erased from collective memory by these processes. I propose that an archipelagic nationalism was produced in Indonesia through a claim to "unity in diversity" which relied on the exclusion of groups within Indonesia's boundaries from that unification.
\end{abstract}

\section{Keywords:}

History, Anthropology, Southeast Asian Studies, Chinese Studies, Anthropology of Food, Nationalism, Malaysia, Communism, Indonesia, China, Empire

\section{Please cite as:}

Oman-Reagan, Michael P. 2013. "Archipelagic Nationalism and Chinese Food Culture in New Order Indonesia: Making Indonesian Food, Erasing Chinese Food." SocArXiv, Open Science Framework. Manuscript, submitted January 23, 2017. osf.io/preprints/socarxiv/cm7eu

\section{Introduction}

During Suharto's “New Order” (1965-1998), ethnic Chinese communities in Indonesia were targeted by assimilationist policies that regulated public celebrations of holidays, use of the Chinese language, economic engagements, citizenship rights, and more. But why did these New Order assimilationist policies not explicitly target Chinese food culture? In this project I aim to explore how colonial inheritances, assimilationist ideology and the emergence of an archipelagic 
nationalism included and excluded Chinese foodways in New Order era embargoes on and erasures of Chinese cultural expression. By looking at the way food was and was not included in the bans on public performances of Chinese culture, I explore how Chinese-Indonesian culture was constructed, produced, and framed in the New Order era in light of the culture bans. I do this by first looking for the historical roots of New Order nationalism and assimilation and seeking to understand how these relations of power informed what was considered Indonesian and what was considered Chinese. I then look at how the Chinese origin of Indonesian food culture was erased from collective memory by these processes.

I begin with the question: what exactly constitutes Indonesia? This question is central to the issue of Chinese food culture in New Order Indonesia because it starts to reveal two key dynamics: first, how it is that Chinese-Indonesians have been and continue to be perceived as a distinct and "special" ethnic group apart from other Indonesians and second, how this status persists despite over 300 non-Chinese ethnic groups in Indonesia making mostly uncontested claims to being authentically "Indonesian."1 In this paper I suggest a possible answer lies within the complex history of relations between colonial and post-independence Indonesia, the Indonesian Communist Party (PKI), the People's Republic of China (PRC) and other forces that have shaped the emergence of the Indonesian nation-state. Although a complete examination of these issues could only be made by beginning with Chinese migration to Indonesia in the fifth century I chose to focus on the period from just before Independence (the 1950s-60s) until the end of the New Order in the late 1990s.

\section{Archipelagic Nationalism: "That is what is called Indonesia."}

Indonesian identity, nationalism, and citizenship are co-produced with the claim that an

$1 \quad$ Tong 2011a:111 
archipelago of approximately 17,000 islands in the Malaysian archipelago constitutes a nation called Indonesia. However, the boundary that defines present-day Indonesia does not correspond to a traditional culture, state or polity - it was and continues to be inherited from the colonial encounter. ${ }^{2}$ The Indonesian national philosophy of Pancasila, engineered publicly first by Sukarno in a series of speeches and then set forth in final form in the 1945 constitution, is part of what ties Indonesia together. It does so by naturalizing the unification of the region's diverse cultural, linguistic, and religious traditions under one nation-state.

In a speech given by Sukarno at Jogjakarta in December 1961, Indonesia's first president offered what would become a lasting idea of what constitutes independent Indonesia's geopolitical boundaries:

". . the Dutch promised that they would recognize sovereignty over the whole of Indonesia. And, friends, what is it that is called Indonesia? What is called Indonesia is the entire archipelago between Sabang and Merauke. What is called Indonesia is what was formerly referred to as the Dutch East Indies. What is meant by Indonesia is what the Dutch called Nederlands Indië, that entire archipelago between Sabang and Merauke which is composed of thousands of islands. That is what is called Indonesia." ${ }^{3}$

In this speech Sukarno drew on the Dutch imperial boundaries to construct the idea of modern, independent Indonesia. The official motto of Indonesia, Bhinneka Tunggal Ika, usually translated as "unity in diversity" refers to a national identity believed to unite the Indonesian people despite ethnic and other differences into a single nation. A related concept, Persatuan Indonesia (Unity of Indonesia) serves as the third principle of Pancasila, the philosophical foundation of the Indonesian state.

Anthropologist Tom Boellstorff notes that social scientists in Indonesia have historically looked at the region in terms of islands of distinct ethnolocalities, taking the people, culture and

2 Boellstorff 2005:7

3 Department of Information N.d. 
language of Bali or Java as subjects, for example rather than Indonesians more broadly. ${ }^{4}$ To counter this ethnolocal tendency (in his ethnography of gay and lesbi Indonesians ${ }^{5}$ ) Boellstorff uses the metaphor of "archipelagic subjectivities" which "do not hew to continental imaginaries of clear borders embracing contiguous territories" but instead reflect the Indonesian national philosophy of unity in diversity as an "archipelago concept."

Drawing on Boellstorff's analysis I propose that under the New Order, Indonesian nationalism became an archipelagic nationalism. By this I mean that Indonesian nationalism was produced through a claim to "unity in diversity" which relied on the exclusion of groups within Indonesia's boundaries from that unification. This exclusion produced islands of nonIndonesian-Indonesians surrounded by seas of state-recognized Indonesians. ChineseIndonesians have been repeatedly subject to exclusion from this archipelagic nationalism, along with the people of West Papua, Maluku, East Timor, Riau, Aceh and others.

As reflected in Sukarno's 1967 speech above, this idea of unity originally resulted in widespread opposition to distinguishing any people within the boundaries of the nation. Historically, this principle of unity was important to the Indonesian independence struggle as a means of fighting the "divide and conquer" methods of imperial and colonial regimes. ${ }^{7}$ Under Dutch colonial rule, the concept of adat (custom/customary/traditional) was elevated to the status of law, and used to frame indigenous cultures and their practices as traditional and natural in opposition to Islam, which was positioned by the Dutch as an invading religion and culture. ${ }^{8}$ However, for both migrant and indigenous people in Indonesia "unity in diversity" has often

4 Boellstorff 2005

5 The Indonesian terms/identities gay and lesbi do not map well onto the English terms gay and lesbian, and Boellstorff's work is not about a GLBTQ community as it is understood to exist in the 'global north.'

6 Boellstorff 2005:7

7 Tsing 2007

8 Tsing 2007 
meant the delegitimizing of their cultural practices in favor of assimilation.

\section{Ruins of Empire: The Rise of the New Order}

The rise of Suharto's military dictatorship to power was accompanied by violent antiChinese sentiment in part because the New Order government blamed the attempted coup on both the PKI and the PRC. Student demonstrations against Suharto persisted through the New Order and the government fought back by instituting compulsory indoctrination in the state philosophy of Pancasila. The goal of this program was "ideological homogeneity." ${ }^{9}$ Assimilation became an important frame in nationalist discourse around the identity and rights of Chinese migrants. The events surrounding the transition from Sukarno's guided democracy to Suharto's New Order set the stage for new waves of anti-Chinese rhetoric and policy, which were pivotal in defining Chinese-Indonesian cultural expression in the era.

Anthropologist Ann Stoler argues that colonial processes are predicated on claims of protecting natural and cultural inheritances for a population assumed to be in need of guidance in order to value and appreciate their inheritance. ${ }^{10}$ Investigating "protracted imperial processes" Stoler looks at "imperial formations" as relations of contemporary force evident in the "ruins of empire" and asks: how does colonial history matter? What do people count as remains? And what do they do with these remains? ${ }^{11}$ By asking how people "live with and in ruins" and turning to ruins as "epicenters of renewed claims, as history in a spirited voice" Stoler hopes that such examinations might uncover "new possibilities, bids for entitlement, and unexpected political projects."12

9 Ricklefs 2001:373

10 Stoler 2008

11 Stoler 2008:192-6

12 Stoler 2008:196-8 
Turning attention to the ruins of empire in Indonesia helps to uncover the complex relationship between divide and conquer techniques of oppression inherited from the Dutch Imperial government and New Order nationalist policy regarding what and whom qualifies as "Indonesian." In New Order Indonesia the ruins of empire both defined the archipelago as a unified nation-state based on boundaries created by the Dutch, and yet also continued to divide the people through a state ideology and policy that officially recognized only certain identities and people as "Indonesian." This dual-sided colonial inheritance made a claim to unity, but also only recognized cultural expression and other human rights for members of officially sanctioned communities. The New Order assimilationist policy toward Chinese-Indonesians reflects both the colonial inheritance as well as the struggle for control of the newly independent Indonesia. In order to understand the position of Chinese migrants in Indonesia, it is necessary to contextualize the frames of identity at play during the construction of the Indonesian subject by tracing the ruins of empire and their echoes through the formation of the independent Indonesia and subsequent New Order government. Rather than include the details of that history here which readers may be familiar with, a brief synopsis is included in Appendix A. Inspired by Stoler's work, I next focus on how Chinese-Indonesians have lived with and in these imperial ruins.

\section{Being Chinese in Indonesia: Assimilation vs. Integration}

In one frequently referenced account first published in 1791, "The Chinaman Abroad: or a Desultory Account of the Malayan Archipelago, particularly of Java," Ong Tae-hae describes how late seventeenth century Chinese immigrants assimilated in Javanese society:

"When the Chinese remain abroad for several generations without returning to their native land, they frequently cut themselves off from the instruction of the sages; in language, food and dress, they imitate the natives, and, studying foreign books [? the Qur'an], they do not scruple 
to become Javanese, when they called themselves Islam (Sit-lam). They then refuse to eat pork and adopt altogether native customs."13

Despite this depiction of Chinese-Indonesian migrants as assimilationist minded, and quick to adopt non-Chinese food culture, more recent accounts show that communities were often divided on the subject. Indonesian archipelagic nationalism produced a contested space of identity in which Chinese-Indonesians were at times able to claim multiple identities while at other times they were forced to enact only either Chinese or Indonesian identity. In the 1950s and 1960s there was an intense debate within the Chinese-Indonesian community about the question of assimilation vs. integration. ${ }^{14}$ The debate was cut short by anti-Chinese violence in 1963 and the anti-communist purges of 1965 but returned again after the riots and political upheaval of May 1998. This renewal of the debate suggests a persistent interest in understanding the implications, values, and dangers of assimilation.

In April 1955 the signing of the Sino-Indonesian Treaty on Dual Nationality set the stage for the approximately 2.45 million ethnic Chinese then living in Indonesia to choose between Indonesian or Chinese (PRC) citizenship. ${ }^{15}$ Adopting Indonesian citizenship required an active declaration in a court that they rejected Chinese citizenship, as a result some Chinese living in Indonesia became officially "Indonesian," some did not and either by choice or default became "aliens" and lost the option to become "Indonesian." ${ }^{16}$ However, after the 1965 coup attempt in Indonesia, relations with China were suspended and in 1969 the Indonesian government abolished the treaty. The Chinese language was banned and materials with Chinese writing could not legally be brought into the country. Beginning in the 1960 s, Chinese language schools in Indonesia have been closed, and Chinese celebrations around lunar New Year were curbed or

13 Ong Tae-hae 1849:24 in Carey 1984

14 Purdey 2003

15 Tan 1997:33

16 Tan 1997:34 
prohibited outside of the home environment. ${ }^{17}$ Chinese ethnic organizations were closed and Chinese-Indonesians were "encouraged" to take Indonesian-sounding names in order to "accelerate the assimilation process." 18

When relations with China resumed in the 1990s, a new Memorandum of Understanding again addressed the status of "Indonesians of Chinese Origin." At the deliberations around this memorandum, both parties agreed that around 300,000 ethnically Chinese people who had been living in Indonesia for decades were still considered aliens. ${ }^{19}$ In one example of local assimilationist policies, in 1996 the governor of Jakarta issued a letter declaring that celebrations of Tahun Baru Imlek (lunar New Year) were occurring "contrary to the regulations in force" and that continuing "these activities would hinder the process of assimilation and threaten the unity of the nation.. ${ }^{20}$ The governor's letter made it clear those celebrations that were Chinese in nature, but not explicitly part of Buddhist religious practices (which are protected under Indonesian law), should occur in the home, and not in public. He further asked that decorations, banners, and other symbols of the celebration, and thus of Chinese culture, should not be put up in public. ${ }^{21}$

However, relying only on narratives of state-level processes masks the production of Chinese identity on the ground in Indonesia. Over the decades from the 1960s to the 1990s, the naturalization process was made easier, the status of the children of naturalized ethic Chinese people was resolved, and with or without participation or consent from the people involved, many ethnic Chinese simply became "Indonesian." Chinese-Indonesian scholar Wang Gungwu argues that in the face of these processes "the cultural identity route to survival and success

17 Tan 1997:42

18 Tong 2011a:124

19 Tan 1997

20 Tan 1997:43

21 Tan 1997:43 
remain[ed] [Chinese-Indonesian's] only option." ${ }^{22}$ These New Order erasures of Chinese cultural identity and processes of compulsory assimilation occurred at multiple scales and levels. In my research I found that the most silent of these, that to which the least literature has been devoted, is the erasure of the Chinese origins of much Indonesian food culture.

\section{Erasing Chinese Food, Making Indonesian Food}

Instead of being subject to assimilationist regulations or prohibition during the New Order, many traditionally Chinese food practices in Indonesia were silently integrated into Indonesian cuisine through erasure of their Chinese origin. Drawing on Barthes' approach to food as a "system of communication, a body of images, a protocol of usages, situations, and behavior" in which food related discourses are understood as culturally specific social forces, I read the re-categorization of Chinese food into Indonesian food as a silencing of Chinese culture equivalent in force to the prohibition on speaking Chinese. ${ }^{23}$ Further, these erasures of Chinesefood origins turn out to be intimately linked to parallel linguistic erasures. ${ }^{24}$

In one study of Chinese loan words in Indonesian (mostly Hokkein), of the 168 words found in the Jakartan dialect a significant number (at least 55) refer to food, for example: bakpao, meat bun; kucai, leek; pecai, white cabbage; bihun, vermicelli; and even chop suey; pangsit. ${ }^{25}$ Mely Tan notes that the erasures of the New Order era persist in language and that "these names of foodstuffs have become so much a part of the Indonesian language that ethnic Indonesians, and even many ethnic Chinese, may not know that they are of Hokkein origin."26

Indonesian scholar Asvi Warman Adam uses tofu as an example, writing:

22 Wang 1988:16

23 Barthes 1997:29

24 I would have liked to include a section here on colonial linguistics, see: Errington 2001 and Irvine \& Gal 2000

25 Tan 2002:155-6

26 Tan 2002:158 
"The noodles eaten every day by many Indonesians came from China. The method of making noodles was then adapted by local ethnic groups so that today we have a variety of noodles, such as Binjai noodles, Belitung noodles, and Aceh noodles. The tofu we enjoy every day was developed by a Chinese settler in Sumedang in 1917. Today, Sumedang is known for its tofu. Other popular foods are bakpao and siomay. Many snacks originated in China, such as hunkue (gelatin made from mung bean flour) and kwaci (dried watermelon seeds). Some kitchen utensils from China are the cobek (mortar), ulekan (pestle), kuali (clay pot), and anglo (clay brazier).",27

Noodles, Tofu, many other foods, cooking implements, and techniques serve as examples of Chinese culture that were assimilated to become "Indonesian," and as Adam also notes the Chinese origin was then "erased from the collective memory" by the New Order regime.

In a 1997 issue of "Jakarta Post Life Style," Mely Tan found at least 80 restaurants serving Chinese food in a ten-page list. ${ }^{28}$ Although this publication targeted an audience of English speakers and upper class educated Indonesians, this anecdote represents the only evidence I found of persistent Chinese restaurant culture in New Order Indonesia. Perhaps these restaurants were serving Chinese food to the same elites who would later come to overthrow Suharto in 1998 ? Or were they serving a role that had been assimilated such that it was no longer considered Chinese? These questions remain unanswered and call for further research through archives and interviews with Chinese-Indonesians.

Although the public celebration of Lunar New Year was prohibited during the New Order, Chinese-Indonesians continued to celebrate in private, and meals were a central component of those celebrations. As one Chinese-Indonesian informant said:

"Some will just celebrate it privately amongst themselves, others will just think of it as another day where they might just eat a meal together without all the formalities and festive mood, while others may celebrate for three days. We will go back to see our parents. We give or exchange ang pows (red packets), we eat lots of food, we gamble, and basically

27 Adam 2003

28 Tan 2002:160 
have a good time off from work. In terms of how big the event is, maybe not as big as in Singapore or Malaysia. We normally only keep it within the family. So I will celebrate with my parents and grandparents and some close relatives. Don't forget that they are traditional Chinese, especially my mother, so Chinese New Year is important for them."29

As the public festival was forced out of the square and into private homes, this informant saw New Years celebrations shift focus toward the meal with family.

In Chee Kiong Tong's fieldwork with Chinese-Indonesians, a majority of the informants identified their Chinese-ness as originating primarily from "ethnicity," descent, or from something in their bodies, and they make no mention of food. ${ }^{30}$ Although the author does not discuss this difference in either text, I noticed that this response stands in stark contrast to the responses of Tong's Chinese-Malaysian informants in a different study who frequently identified their Chinese-ness as also having to do with food culture. ${ }^{31}$ In one example, an informant said:

"I think the biological part comes first, being born of Chinese parents. Second is the practicing of Chinese culture. The food aspect, I think, is one thing that binds all Chinese. Food, I consider the most important. Certain Chinese traits, such as, family togetherness, practice of Chinese festivals, are also important. Religion will not define Chineseness. I would disqualify clothes too. Chinese do not wear cheongsam anymore. ${ }^{32}$

In both Malaysia and Indonesia, primarily non-Muslim ethnic Chinese populations live with a majority Muslim population - however in Malaysia the ethnic Chinese make up about 26\% of the population, whereas in Indonesia they are only about 3\%. This difference in numbers is no doubt a factor, but I suggest the more significant differences are the unique historical relations of power, the colonial inheritances from the Dutch Imperial government (vs. the British in Malaysia), and the construction of archipelagic nationalism under the New Order regime.

29 Tong $2011 \mathrm{a}: 130$

30 Tong 2011a

31 Tong 2011b

32 Tong 2011b:97 
In Indonesia, the New Order worked to erase the importance of contributions by ChineseIndonesians in order to maintain a definition of Indonesian identity consistent with anti-PRC, anti-Communist discourse. Rather than explicitly prohibit the public consumption of Chinese food culture, the Chinese-ness of the food was erased and it was made "Indonesian." While this assimilation of Chinese food into Indonesian food began long before the New Order, the nationalist and assimilationist policies of the New Order represented a new force working to systematically erase the memory of its origins.

Postscript: Chinese Food culture after Reformasi:

Since the end of the New Order, official policy has been less explicitly anti-Chinese. As Hoon reports:
"In the aftermath of the May 1998 riots that forced President Suharto to step down, ethnic Chinese received unprecedented freedom to assert their long suppressed cultural and religious identity. Following the transition from assimilation to multiculturalism, for the first time in over three decades Chinese culture became more visible and ethnic Chinese could finally enjoy the freedom to celebrate Chinese New Year (Imlek) publicly., 33

In 2001 Chinese New Year was declared a national holiday, and families could finally leave the dining room to celebrate in public. However as the history of anti-Chinese sentiment and policy in Indonesia suggests, Chinese culture remains under threat in Indonesia. As Islamic nationalist movements, backed by the police and military, continue to gain popular support and influence within government - Chinese food culture, especially that which makes use of Pork, faces returning threats of prohibition and erasure.

33 Hoon 2009:1 


\section{Appendix A: Nationalism, Assimilation and The Rise of the Anti-Chinese New Order}

Following the surrender of Japan on August 15th, 1945, Indonesian youth leaders (along with Sukarno and others) drafted an independence declaration that was read on August 17 th. $^{34}$ When allied forces arrived expecting to return Indonesia to the colonial regime, they found a war of independence, a nation divided between left and right, young and old, Islamic and secular, Dutch and Indonesian. ${ }^{35}$ In a speech called "The Birth of Pancasila" Sukarno outlined the ideals behind what he envisioned as the binding national philosophy of the new Indonesian nation Pancasila: Kebangsaan Indonesia. (Nationality of Indonesia); Internasionalisme, - atau perikemanusiaan. (Internationalism or Humanity/Humanism); Mufakat, - atau demukrasi. (Consensus or Democracy); Kesejahteraan sosial. (Social Welfare).

After five years of revolutionary conflict, factions unified enough to replace a divided state with the Republic of Indonesia under a unitary constitution in $1950 .{ }^{36}$ It was during these years that the Indonesian communist party (Partai Komunis Indonesia, PKI) regained strength and built the foundation of what would soon become the world's largest non-ruling communist party. Despite the apparent unity of the nation by the early 1950 s, over the next few decades the military, the PKI and Islamic nationalist separatist movements all struggled for power. From 1957 to 1965 Sukarno ruled with the philosophy of Demokrasi Terpimpin (Guided Democracy) based on traditional village structures of consensus supplemented with guidance from elders. At the core of his Guided Democracy was an attempt to bring together the factions in Indonesia by blending nasionalisme (nationalism), agama (religion), and komunisme (communism).

Sukarno's power and legitimacy as president of the newly independent nation depended on balancing these three forces, especially the tensions between an increasingly antagonistic 
military (nationalism) and PKI (communism). In the early to mid-1960s, Sukarno's rhetoric became more anti-western and the PKI gained more power throughout every level of the government. In his Independence Day speech on August 17th 1965, Sukarno announced an "antiimperialist Jakarta-PhnomPenh-Hanoi-Beijing-Pyongyang axis" and implied that only the military was standing in the way of this plan. ${ }^{37}$ In response, on September $30^{\text {th }}$ a battalion of palace guards attempted a coup. Major General Suharto took command of the military announcing that he would stop the coup and protect Sukarno, but then refused to return control of the military. Weakened as president, Sukarno was forced to transfer powers to Suharto over the course of the next year. Suharto was named president in March 1967 and he established what came to be known as the "New Order" in contrast to the "old order" of Sukarno's presidency. During the first year after the coup attempt, Suharto ordered a massacre of PKI members, their family and suspected members - perhaps 1 million or more were murdered by the first months of $1966^{38}$

37 Ricklefs 2001:338

38 Ricklefs 2001:347 


\section{References Cited}

Adam, Asvi Warman

2003 The Chinese in the Collective Memory of the Indonesian Nation. Kyoto Review of Southeast Asia 3. http://kyotoreview.cseas.kyoto-u.ac.jp/issue/issue2/article_244.html, accessed April 9, 2013.

Barthes, Roland

1997 Toward a Psychosociology of Contemporary Food Consumption. In Carole Counihan and Penny Van Esterik, ed. Food and Culture: A Reader, Routledge 2: 28-35.

Boellstorff, Tom

2005 The Gay Archipelago: Sexuality and Nation in Indonesia. Princeton Univ Pr.

Carey, Peter

1984 Changing Javanese Perceptions of the Chinese Communities in Central Java, 1755-

1825. Indonesia(37): 1-47.

Department of Information

N.d. "The People's Command For The Liberation Of West Irian" Given by the President/Supreme Commander of the Armed Forces of the Republic of Indonesia. Commander-in-Chief of the Supreme Command for the Liberation of West Irian at a mass meeting in Jogjakarta, on 19th December 1961. Department Of Information, Republic Of Indonesia, Special Issue, No.82

Errington, Joseph

2001 Colonial Linguistics. Annual Review of Anthropology 30(1): 19-39.

Hoon, Chang Yau

2009 More Than a Cultural Celebration: The Politics of Chinese New Year in Post-Suharto Indonesia. Chinese Southern Diaspora Studies 3: 90 - 105.

Irvine, Judith T. \& Susan Gal

2000 Language Ideology and Linguistic Differentiation. in Kroskrity, P. (Ed.), Regimes of language : ideologies, polities, and identities, (pp. 35-83). Santa Fe, NM; Oxford: School of American \# Research Press; J. Currey.

Purdey, Jemma

2003 Political Change Reopening the Asimilasi vs Integrasi Debate: Ethnic Chinese Identity in post-Suharto Indonesia. Asian Ethnicity 4(3): 421-437.

Ricklefs, M. C.

2001 A History of Modern Indonesia Since c. 1200. Stanford Univ Pr.

Stoler, Ann L. 
2008 Imperial Debris: Reflections on Ruins and Ruination. Cultural Anthropology 23(2): 191-219.

Suryadinata, Leo

1976 Indonesian Policies Toward the Chinese Minority Under the New Order. Asian Survey 16(8): 770-787.

Tan, Mely G.

2002 Chinese Dietary Culture in Indonesian Urban Society. The Globalization of Chinese Food: 152.

1997 The Ethnic Chinese in Indonesia: Issues of Identity. Ethnic Chinese as Southeast Asians: $33-65$.

Tong, Chee Kiong

2011a Between a Rock and a Hard Place: The Chinese in Indonesia. in Identity and Ethnic Relations in Southeast Asia Pp. 111-145. Springer Netherlands.

2011b Sama Makan Tak Sama Makan: The Chinese in Malaysia. In Identity and Ethnic Relations in Southeast Asia Pp. 83-110. Springer Netherlands.

Tsing, Anna Lowenhaupt

2007 Indigenous Voice. Indigenous Experience Today: 35-68.

Wang, Gungwu

1988 The Study of Chinese Identities in Southeast Asia. Changing Identities of the Southeast Asian Chinese Since World War II in Cushman, Jennifer Wayne, and Gungwu Wang. 1988. Changing Identities of the Southeast Asian Chinese Since World War II. Hong Kong University Press. 